\section{Wildlife protection and indigenous people}

In the 'News and views' section of the January 1987 issue of Oryx (21, 4-5), Brian Morris reported on the 4th International Conference on Hunting and Gathering Societies, and discussed the complex and sometimes conflicting objectives of cultural and natural preservation.

The identification of World Wildlife Fund with a lack of sensitivity on this question does not recognize the major programme initiatives that have been under way within WWF for some time. For example, at World Wildlife Fund-US I direct the Programme in Wildlands and Human Needs, whose overall goal is to improve management of critical wildland areas to ensure that they can be used sustainably in order to meet the development needs of rural people.

Some of these activities have a strong anthropological orientation, such as the ethnobotany studies that we have sponsored in Suriname and work with the Kayapo in Brazil, and many have the dual goal of both cultural and natural resource preservation. In the Kuna Indian Forest Reserve in Panama, for example, it is the native people themselves who have established the protected area and are implementing management programmes with our assistance.

In other areas World Wildlife Fund is working to establish land rights for native peoples, including projects on the south-east coast of Costa Rica, in Irian Jaya in Indonesia, and jointly with Cultural Survival with the Awa Indians of Colombia and Ecuador.

Other project approaches aim at incorporating indigenous groups, not only in programme activities but also in the actual planning and implementation of projects; examples include the Paya and Miskitos in the Rio Platano of Honduras, the Choco, Wainan and Kuna of the Darien, the Sione Secoya in the Cuyabeno of Ecuador and the Cabecar in Costa Rica's Amistad Biosphere Reserve.

WWF-US has not specifically singled out tribal peoples for its conservation and development projects, but seeks to address the needs of rural populations, be they Indians or campesinos, in and around protected areas. Thus we are working to establish extractive reserves for Brazil's rubber tappers, sustainable use in Peru's huge Pacaya Samiria Reserve, a cottage forestry programme in the tropical forests of Dominica, a lobster fishery project in Sian Kaan of Mexico, a wildlife utilization project in Zambia's Luangwa Valley, and fuelwood and fisheries extension work both on the Caribbean island of St Lucia and at the biologically diverse Lake Malawi in Africa.

A local village credit system is now under consideration in northern Thailand, as is a health system linked to a local reserve for the BaBinga pygmies in the CAR, a project with the Uros indians of Lake Titicaca of Peru, and another with the Chemonies of Bolivia. We are seeking funding, and plan to host a workshop on 'Natural Resources Management and Native Peoples' drawing on indigenous groups from the US, Canada and Latin America.

I cannot speak from pesonal experience regarding the Chenchus of Andhra Pradesh, which prompted the Oryx article, but I hope the diversity and range of projects being undertaken by just one of the WWF organizations will demonstrate that the balancing of human and natural needs is not an insignificant or incidental part of World Wildlife Fund's activities.

We at WWF recognize that the interest of native peoples and nature conservation will not always be identical, but with good will our two communities will find that what unites us far overweighs what divides us. Dr Morris has made an important contribution in urging that such a dialogue is overdue, and I hope that this response will take the discussion one step further.

R. Michael Wright, Vice-President, WWF-US, 1255 Twenty Third Street, NW. Washington, DC 20037. USA.

\section{The rarest lemurs on earth}

The 'rediscovery' by Patricia Wright of Duke University of the greater bamboo or broad-nosed gentle lemur Hapalemur simus has been widely reported (Los Angeles Times, 28 September 1986; Nature, 16 October 1986; Oryx, 21, 117). I 
should like to correct the misleading impressions given by these reports.

The population of $H$. simus that Dr Wright has been studying lives in degraded rain forest near the beautiful village of Ranomafana, famous for its geothermal baths and something of a resort before Madagascar became independent in 1960. Unfortunately, the forest in which they live is not remote (as stated in the reports), but is less than a kilometre from a good tarmac road (a rarity in Madagascar). This facilitates the easy export of timber by commercial concerns.

Patricia Wright has done some impressive pioneering work on assessing the conservation status of these lemurs and on habituating a troop of four to human observers. The German primatologist, Bernhard Meier, has continued this excellent work, spending many months in leechinfested forest, meticulously detailing their ecological needs and contributing to local conservation education. There are now encouraging moves to set up a reserve for the greater bamboo lemurs; this would also protect other sympatric lemurs including the diadem sifaka Propithecus diadema, the rarely seen red-bellied lemur Lemur rubriventer and the woolly lemur Avahi laniger.

The Ranomafana population of $H$. simus has been well known for several decades to the Malagasy and to two French ecologists, Drs A. Peyriéras and J. J. Petter (presumably the 'two Frenchmen' who captured a pair in 1972). Indeed the species bred in captivity in Madagascar's zoological gardens, Parc Tzimbazaza, and at least one $H$. simus was at the zoo until 1978.

Most French scientists and advisers left Madagascar around 1970 for political reasons, and it was not until the early 1980s that Madagascar again began to welcome foreign biologists; information on Madagascar's fauna and flora remained in the country during the intervening years. Madagascar is much more accessible now, and there are many exciting projects involving the co-operation of Malagasy and foreign scientists (Durrell, 1986); the British Embassy told me that more than 50 British biologists visited Madagascar in the summer of 1986. With the increasing amount of scientific field work that is going on, we are getting far more

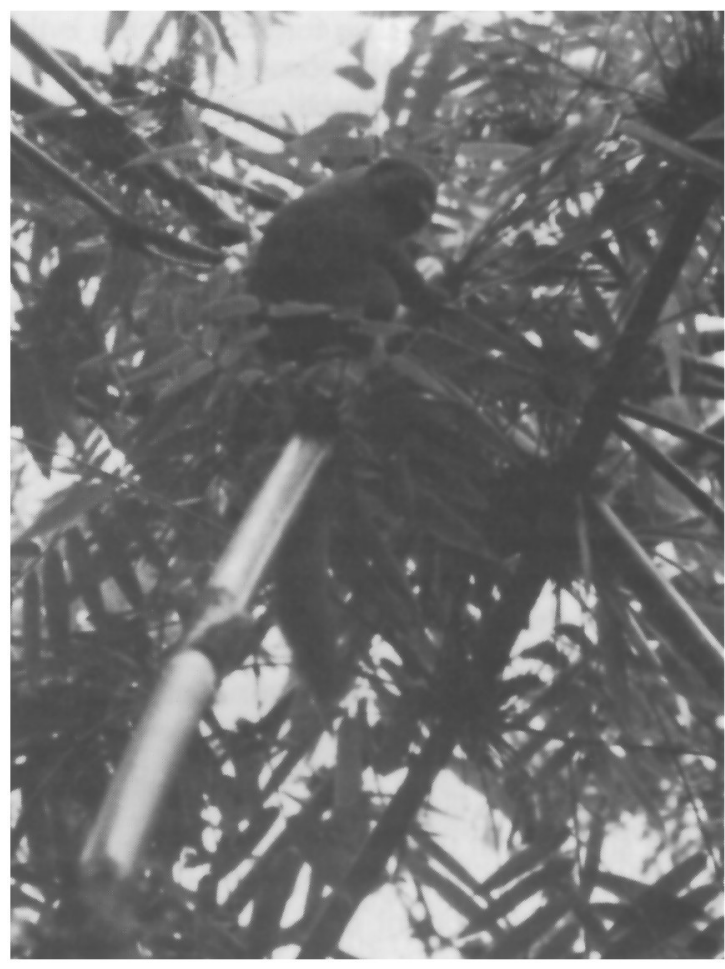

Hapalemur simus in forest near Ranomafana (Simon Howarth).

information on other rare species. The secretive and rarely seen aye-aye Daubentonia madagascariensis, for example, is now being recorded from numerous locations and is probably much more widespread than ecologists previously believed. Its unenviable place as the world's rarest lemur has been usurped by $H$. simus. When I visited Ranomafana in December 1986, Bernhard Meier believed that there were $60-80 \mathrm{H}$. simus living in the area, their only known refuge. This tiny remaining population means that they are perilously close to extinction.

$H$. simus must have once been quite common throughout Madagascar (Vuillaume-Randriamanantana et al., 1985). During the 1986 Crocodile Caves of Ankarana Expedition (see Wilson, 1987, for a description of the 1981 Expedition to Ankarana) we discovered 18 skeletons of $H$. simus, which must have been living in the semi-deciduous forests of the area. This is $1000 \mathrm{~km}$ north of Ranomafana. We also found evidence of a lemur feeding on the 
bamboo of the Ankarana forests, so there is the exciting possibility that a second population of $H$. simus is living on in a remote pocket of this littleknown reserve.

\section{References}

Durrell, L. 1986. Wildlife research in Madagascar: how foreigners are helping. Oryx, 20, 10-14.

Vuillaume-Randriamanantana, M., Godfrey, L.R. and Sutherland, M.R. 1985. Revision of Hapalemur gallieni. Folia primatologica, 45, 89-116.

Wilson, J.M. 1987. The crocodile caves of Ankarana, Madagascar. Oryx, 21, 43-47.

Dr Jane M. Wilson, 69 Thame Road, Warborough, Oxfordshire OX9 8EA, UK.

The 'rediscovery' of Hapalemur simus last year has been publicized widely, with even national newspapers taking an interest. It is to be hoped that the lemurs will benefit from the publicity, but it is a shame that unwarranted claims have been made. Certainly, the relocation of $H$. simus is an exciting and important find. Unfortunately, not one of the many news items I have read properly acknowledges or even names the two Frenchmen, Jean-Jacques Petter and André Peyrieras, who rediscovered the lemur in 1972 after it had not been seen for 100 years.

The species is undoubtedly rare; it is also secretive and has a localized distribution, but, had an effort been made to look for it between 1972 and 1986 , it is likely that it would have been found. This view is upheld by the fact that the 1986 expedition to look for the species found it where J. -J. Petter and A. Peyrieras discovered it. If every species were declared extinct after such a brief period of not being seen, the list of extant mammals would be greatly reduced.

Petter and Peyrieras, both of whom have vast experience in Madagascar, have been overlooked in the recent publicity. They, amongst others, would not have presumed that this lemur was extinct. A degree of tact when announcing such claims as this would go a long way to promote international co-operation in wildlife conservation.

Mark Pidgeon, The Black House, Long Reach, Chesterton, Cambridge CB4 1UN, UK

182

\section{The WWF and Gunung Leuser National Park, Sumatra}

Our attention has been drawn to an incorrect statement in an otherwise excellent article by Michael Ghiglieri in Oryx (Volume 20, April 1986). On page 109 the author quotes the WWF as having sponsored the expensive failure of the Uning Puni relocation project. In fact, our role in Gunung Leuser has always been orientated towards providing scientific and managerial advice to the Forest Protection and Nature Conservation Service. Since the early 1970s the WWF has supported a succession of scientists and park advisers who have counselled our Indonesian colleagues on management problems, including advice on how to deal with population enclaves within the park. The WWF has never been involved in any operational aspects of the Uning Puni relocation project.

Anton Fernhout, Projects Management Department, WWF International, CH-1196 Gland, Switzerland.

\section{A park with a kangaroo problem}

David Cheal's discussion of the rehabilitation of Hattah-Kulkyne National Park (Oryx, 20, 95-99) is misleading in its outline of the historical changes to the park's fauna. Cheal claims that kangaroos were 'very rare' or 'scarce' in northwestern Victoria prior to European settlement, citing Wakefield's analysis of the progress of the Blandowski expedition. However, Wakefield's analysis clearly shows that the diary of the expedition covered only the period from December 1856, when the expedition left Melbourne, to March 1857, by which time it had reached Lake Boga and was still some $130 \mathrm{~km}$ south-west of Hattah-Kulkyne National Park. Up to that stage, the diary referred to kangaroos (almost certainly the eastern grey kangaroo Macropus giganteus, not the western grey kangaroo $M$. fuliginosus) as 'scarce'.

The expedition later established a camp near the present site of Mildura, about $45 \mathrm{~km}$ north of the park. There, other records of the expedition described the western grey kangaroo as "very common on both sides of the Murray' and 'much 